Przegląd Prawa Konstytucyjnego

- -ISSN 2082-1212--------

DOI 10.15804/ppk.2015.01.03

$-\mathrm{Nr} 1(23) / 2015$

Katarzyna Orzechowska ${ }^{1}$

\title{
Ostateczność orzeczeń Trybunału Konstytucyjnego w regulacjach obowiązujących przed 1997 r. oraz koncepcje ostateczności orzeczeń Trybunału Konstytucyjnego w trakcie prac Komisji Konstytucyjnej Zgromadzenia Narodowego i w projektach Konstytucji
}

Słowa kluczowe: ostateczność orzeczeń, Komisja Konstytucyjna Zgromadzenia Narodowego, sądownictwo konstytucyjne, transformacja ustrojowa, projekty konstytucji Keywords: finality of judgements, Constitutional Commission of the National Assembly, constitutional judicature, political transformation, drafts of the constitution

\section{Streszczenie}

Celem publikacji jest omówienie zagadnienia ostateczności orzeczeń Trybunału Konstytucyjnego. Dostrzegalną datą w historii tego zagadnienia jest 1997 r., co związane jest z uchwaleniem Konstytucji. W okresie od początku sądownictwa konstytucyjnego (czyli od 1982 r.) aż do uchwalenia Konstytucji RP dominował, uwarunkowany systemem politycznym, pogląd o braku potrzeby ustanowienia wszelkich pozaparlamentarnych (a tym bardziej niezależnych od parlamentu) form kontroli konstytucyjności stanowionego prawa. Skutkowało to tym, że orzeczenia Trybunału o niezgodności ustaw z przepisami konstytucyjnymi poddane zostały kontroli władzy ustawodawczej. W wyniku zasadniczych zmian ustrojowych po 1989 r. rozpoczęły się prace zmierzające do uchwalenia nowej konstytucji. Formalny początek prac datowany jest na dzień 7 grudnia 1989 r., kiedy to powołane zostały do życia Komisje Konstytucyjne każdej z izb Parlamentu, a później Komisja Konstytucyjna Zgromadzenia Narodowego. To właśnie

Autorka jest doktorantką na Wydziale Prawa i Administracji Uniwersytetu Łódzkiego. Mail:korzechowska@poczta.fm. 
podczas prac KKZN dyskutowano nad zagadnieniem ostateczności orzeczeń. W pracy omówię właśnie tę dyskusję i przedstawię koncepcje ostateczności orzeczeń Trybunału Konstytucyjnego w projektach konstytucji, by w końcu przedstawić model ostateczności orzeczeń przyjęty w Konstytucji RP z 1997 r.

\section{Summary}

\section{The finality of judgments of the Constitutional Court in the regulations before 1997 and concepts of finality of judgments of the Constitutional Court during the work of the Constitutional Commission of the National Assembly and in the drafts of Constitution}

The aim of this publication is to discuss issues of finality of judgments of the Constitutional Court. Noticeable date in the history of this matter is year 1997, which is associated with the enactment of the Constitution. From beginning of the constitutional judiciary (since 1982) until the enactment of the Constitution of the Republic of Poland, a view of lack of need for any extra-parliamentary (and even more independent of parliament) forms of the constitutionality of legislation dominated the scene. And it was conditioned by the political system. This meant that the Constitutional Tribunal's ruling of non-compliance with the provisions of the constitutional laws have been subjected to the control of the legislature. Work towards adoption of the new Constitution began as a result of a major political changes after 1989. Actual beginning of the work is dated on 7 December 1989, when Constitutional Commissions of each of the houses of the Parliament were appointed, and later on the Constitutional Commission of the National Assembly. It was during the work of the Constitutional Commission of the National Assembly when issue of finality of judgments was discussed. In this article I will discuss that discussion and introduce concepts of finality of judgments of the Constitutional Court in the drafts of Constitution, to finally present a model of finality of judgements adopted in the Constitution of 1997.

Celem publikacji jest omówienie zagadnienia ostateczności orzeczeń Trybunału Konstytucyjnego. Dostrzegalną datą w historii tego zagadnienia jest 1997 r., co związane jest z uchwaleniem Konstytucji. W okresie od początku sądownictwa konstytucyjnego (czyli od 1982 r.) aż do uchwalenia Konstytucji RP dominował, uwarunkowany systemem politycznym, pogląd o bra- 
ku potrzeby ustanowienia wszelkich pozaparlamentarnych (a tym bardziej niezależnych od parlamentu) form kontroli konstytucyjności stanowionego prawa. Skutkowało to tym, że orzeczenia Trybunału o niezgodności ustaw z przepisami konstytucyjnymi poddane zostały kontroli władzy ustawodawczej. W wyniku zasadniczych zmian ustrojowych po 1989 r. rozpoczęły się prace zmierzające do uchwalenia nowej konstytucji. Formalny początek prac datowany jest na dzień 7 grudnia 1989 r., kiedy to powołane zostały do życia Komisje Konstytucyjne każdej z izb Parlamentu, a później Komisja Konstytucyjna Zgromadzenia Narodowego (dalej także jako: „KKZN”). To właśnie podczas prac KKZN dyskutowano nad zagadnieniem ostateczności orzeczeń. W pracy omówię właśnie tę dyskusję i przedstawię koncepcje ostateczności orzeczeń Trybunału Konstytucyjnego w projektach konstytucji, by w końcu przedstawić model ostateczności orzeczeń przyjęty w Konstytucji Rzeczypospolitej Polskiej z 1997 r.

I.

Historia polskiego sądownictwa konstytucyjnego rozpoczęła się w dniu 26 marca 1982 r., kiedy to Sejm przyjął ustawę o zmianie Konstytucji Polskiej Rzeczypospolitej Ludowej (dalej jako: „nowela konstytucyjna z 1982 r.”). Na podstawie tej noweli do treści ustawy zasadniczej wprowadzony został art. 33a i 33b w rozdziale, któremu nadano tytuł „Trybunał Konstytucyjny, Trybunał Stanu, Najwyższa Izba Kontroli”. Tym samym utworzony został Trybunał Konstytucyjny jako podmiot uprawniony do orzekania o zgodności z Konstytucją ustaw i innych aktów normatywnych naczelnych oraz centralnych organów państwowych. Sama nowela konstytucyjna nie wystarczyła jednak do powstania Trybunału Konstytucyjnego. Właściwość, ustrój i postępowanie przed Trybunałem określać miała bowiem ustawa, która została uchwalona dopiero w 1985 r., a weszła w życie z dniem 1 stycznia 1986 r. ${ }^{3}$ (dalej jako: „ustawa o Trybunale Konstytucyjnym z 1985 r.”).

2 Ustawa z dnia 26 marca 1982 o zmianie Konstytucji Polskiej Rzeczypospolitej Ludowej (Dz.U. Nr 11, poz. 83).

3 Ustawa z dnia 29 kwietnia 1985 r. o Trybunale Konstytucyjnym (Dz.U. Nr 22, poz. 98 ze zm.). Zastrzec należy, iż z dniem ogłoszenia, czyli z dniem 14 maja 1985 r., wszedł w ży- 
W czasach państwa socjalistycznego, czyli w systemie jednolitej władzy, przyjmującym zasadę zwierzchniej pozycji parlamentu (w ówczesnych warunkach - partii ludowej), dominował pogląd o braku potrzeby ustanowienia jakichkolwiek pozaparlamentarnych form kontroli konstytucyjności stanowionego prawa. Tymczasem utworzenie Trybunału Konstytucyjnego, jako pozaparlamentarnego organu, stworzyło przesłanki ukształtowania skutecznych gwarancji przestrzegania Konstytucji w procesie tworzenia pra$\mathrm{wa}^{4}$. Przyjęty model był przy tym wyrazem kompromisu między stworzeniem sądownictwa konstytucyjnego a utrzymaniem zasady jednolitości władzy państwowej. W tej sytuacji nie może dziwić, że pozycja i uprawnienia Trybunału Konstytucyjnego, szczególnie w początkowym okresie, były znacząco ograniczone. Jednym z najistotniejszych ograniczeń w tym zakresie było przyjęcie, już w noweli konstytucyjnej z 1982 r., iż orzeczenia Trybunału o niezgodności ustaw ${ }^{5}$ z Konstytucją podlegały rozpatrzeniu przez Sejm (art. 33a ust. 2 Konstytucji z 1952 r.) $)^{6}$. Tym samym orzeczenia Trybunału o niezgodności ustaw z przepisami konstytucyjnymi poddane zostały kontroli władzy ustawodawczej. Tryb i zasady tej kontroli regulował przepis art. 7 ustawy o Trybunale Konstytucyjnym z 1985 r., wskazując, iż orzeczenia stwierdzające niezgodność z Konstytucją aktu ustawodawczego prezes Trybunału Konstytucyjnego przedkłada Sejmowi, a jeżeli z wnioskiem wystąpił prezydent - także jemu. Sejm rozpatrywał takie orzeczenie nie później niż w okresie sześciu miesięcy od dnia przedstawienia orzeczenia przez prezesa Trybunału Konstytucyjnego7. Uznanie przez Sejm zasadności orzeczenia łą-

cie przepis art. 32 (dotyczący uchwalenia szczegółowego trybu postępowania i regulaminu czynności Trybunału Konstytucyjnego) i art. 34 (dotyczący zasad wyboru pierwszego składu Trybunału Konstytucyjnego).

4 M. Mazurkiewicz, Orzecznictwo Trybunatu Konstytucyjnego jako inspiracja w pracach nad Konstytucja z dnia 2 kwietnia 1997 roku, [w:] Księga XX-lecia orzecznictwa Trybunatu Konstytucyjnego, Warszawa 2006, s. 187.

5 Opisywana procedura odnosi się do aktów ustawodawczych, czyli ustaw zwykłych i dekretów z mocą ustawy.

6 Powołany przepis dotyczył tylko ustaw, a contrario nie miał zastosowania do aktów podustawowych.

7 Zgodnie z tekstem pierwotnym ustawy o Trybunale Konstytucyjnym z 1985 r. - wówczas był to art. 6 ust. 2 - przedłożone przez prezesa Trybunału Konstytucyjnego orzeczenie o niezgodności aktu ustawodawczego z Konstytucją Sejm rozpatrywał podczas bieżącej lub najpóźniej podczas najbliższej sesji. Po nowelizacji ustawy o Trybunale Konstytucyjnym doko- 
czyło się z koniecznością dokonania odpowiednich zmian w ustawie objętej tym orzeczeniem bądź uchyleniem jej w całości lub w części. Natomiast gdy Sejm nie podzielał poglądu Trybunału, oddalał orzeczenie, a sprawa nim objęta nie mogła być ponownie przedmiotem postępowania przed Trybunałem (art. 7 ust. 3 ustawy o Trybunale Konstytucyjnym z 1985 r.). Uchwały Sejmu w sprawach oddalenia orzeczenia Trybunału zapadały większością co najmniej 2/3 głosów, w obecności co najmniej połowy ogólnej liczby posłów (art. 7 ust. 4 ustawy o Trybunale Konstytucyjnym z 1985 r.). Jednakże powołany przepis nie zawierał żadnej regulacji dotyczącej sytuacji, w której Sejm naruszył termin do zajęcia stanowiska w przedmiocie orzeczenia trybunalskiego, co skłoniło Rzecznika Praw Obywatelskich do wystąpienia do Trybunału Konstytucyjnego z wnioskiem o ustalenie powszechnie obowiązującej wykładni art. 7 ust. 2 ustawy o Trybunale Konstytucyjnym z 1985 r. W odpowiedzi na ten wniosek Trybunał przyjął uchwałę ${ }^{8}$, która miała istotne znaczenie dla rozumienia obowiązku Sejmu rozpatrzenia orzeczenia Trybunału i skutków zaniedbania tego obowiązku. W powołanej uchwale potwierdzono, że Sejm miał sześciomiesięczny termin na rozpatrzenie orzeczenia od dnia przedstawienia tegoż orzeczenia Sejmowi przez prezesa TK, wskazując nadto, iż w tym terminie Sejm podzielając pogląd składu orzekającego TK, powinien dokonać odpowiednich zmian w ustawie bądź uchylić ją w części lub całości. Co najważniejsze z punktu widzenia niniejszej publikacji - orzeczenie Trybunału, które nie zostało rozpatrzone przez Sejm w terminie sześciu miesięcy, miało (zachowywało) moc obowiązującą i - co należy szczególnie zaakcentować - skutkowało uchyleniem ustawy z dniem ogłoszenia w Dzienniku Ustaw obwieszczenia prezesa TK o utracie mocy obowiązującej ustawy. Motywując swój pogląd w tym zakresie, Trybunał w uzasadnieniu powołanej uchwały wyraził opinię, iż termin określony w art. 7 ust. 2 ustawy o Trybunale Konstytucyjnym z 1985 r. to termin zawity, a Sejm nie miał prawa go przekroczyć. Przyjęcie tezy przeciwnej - w oce-

nanej mocą ustawy z dnia 29 maja 1989 r. o przekazaniu dotychczasowych kompetencji Rady Państwa prezydentowi Rzeczypospolitej Polskiej Ludowej i innym organom państwowym (Dz.U. Nr 34, poz. 178), która weszła w życie z dniem 19 lipca 1989 r., wprowadzono termin 6 miesięcy dla Sejmu na zajęcie stanowiska w przedmiocie orzeczeń Trybunału Konstytucyjnego. Nowelizacja związana była z rezygnacją z sesyjnego systemu pracy Sejmu.

8 Uchwała Trybunału Konstytucyjnego z dnia 20 października 1993 r., sygn. akt W 6/93. 
nie Trybunału - oznaczałoby powrót do nieobowiązującej już wówczas zasady pełni władzy i nadrzędności Sejmu. Uzasadniając natomiast swój pogląd odnoszący się do skutków nierozpatrzenia przez Sejm orzeczenia Trybunału, tenże podkreślił, iż naruszenie przez Sejm tego obowiązku nie wpływało na moc obowiązującą orzeczenia, a czyniło jedynie bezskutecznym warunek prawny rozpatrzenia takiego orzeczenia przez Sejm. Przyznając, że brak jest w tym zakresie wyraźnego postanowienia w obowiązujących przepisach prawa, Trybunał takiej podstawy dopatrzył się w trybunalskiej kompetencji do orzekania o zgodności prawa z Konstytucją, która swoje źródło czerpie z Konstytucji, zatem z aktu najwyższej rangi.

Pozostając nadal w temacie uprawnienia Sejmu do rozpatrzenia orzeczenia trybunalskiego, dostrzec wypada pogląd Tadeusz Skrzypczaka9 ${ }^{9}$. Autor podkreślił, iż Sejm posiadając uprawnienie do rozpatrywania orzeczeń trybunalskich, zyskiwał na znaczeniu, bowiem orzeczenia Trybunału odnoszące się do aktów ustawodawczych były nieskuteczne. Dalej zwracając uwagę na szczególny tryb oddalenia orzeczenia TK (większość kwalifikowania), autor dowodził tezy, iż efektem oddalającego orzeczenie Trybunału działania było podniesienie zakwestionowanej w nim regulacji do rangi ustawy konstytucyjnej. W końcu autor wyraził pogląd, że do polskiego systemu prawa - na skutek regulacji art. 7 ust. 3 i 4 ustawy o Trybunale Konstytucyjnym z 1985 r. - wprowadzono „nierewizyjną ustawę konstytucyjną”10.

Powyższe zasady - jak już sygnalizowałam wcześniej - nie dotyczyły aktów rangi niższej niż ustawa. $\mathrm{W}$ tym przypadku sytuacja przedstawiała się zgoła odmiennie, bowiem prezes TK miał obowiązek przedłożenia orzeczenia stwierdzającego niezgodność z Konstytucją lub aktem ustawodawczym aktów wydanych przez prezydenta, naczelne i centralne organy administracji państwowej oraz inne naczelne i centralne organy państwowe (art. 8 w zw. z art. 1 pkt 2 ustawy o Trybunale Konstytucyjnym z 1985 r.) tymże organom. W takim przypadku organ, który wydał akt objęty orzeczeniem, winien dokonać niezwłocznie odpowiednich zmian w tym akcie lub go uchylić

9 T. Skrzypczak, Wyktadnia autentyczna czy nowy rodzaj normy prawnej, [w:] Konstytucja w społeczeństwie obywatelskim. Księga pamiątkowa ku czci Prof. W. Zakrzewskiego, red. K. Działocha, Kraków 1989, s. 177-184.

$10 \mathrm{~W}$ przeciwieństwie do rewizyjnych ustaw konstytucyjnych w tych nierewizyjnych nie dochodzi do zmiany regulacji. 
w całości lub w części, nie później niż w terminie trzech miesięcy od przedłożenia orzeczenia Trybunału (art. 9 ust. 1 ustawy o Trybunale Konstytucyjnym z 1985 r.). W razie zaniedbania tego obowiązku zakwestionowany akt tracił moc $\mathrm{z}$ upływem trzymiesięcznego terminu w zakresie określonym w orzeczeniu Trybunału (art. 10 ust. 1 ustawy o Trybunale Konstytucyjnym z 1985 r.). Powyższe uwagi należy uzupełnić o wzmiankę o szczególnym uprawnieniu Trybunału do zawieszenia w całości lub w części zakwestionowanego aktu z dniem ogłoszenia do upływu trzymiesięcznego terminu na uchylenie lub zmianę zakwestionowanych regulacji przez normodawcę (art. 10 ust. 2 ustawy o Trybunale Konstytucyjnym z 1985 r.). Wspomniana instytucja zawieszenia miała charakter wyjątkowy, gdyż znajdowała zastosowanie tylko „w szczególnie uzasadnionych wypadkach”, co expressis verbis wynikało z treści art. 10 ust. 2 ustawy o Trybunale Konstytucyjnym z 1985 r.

Ustawa przewidywała także - w art. 30 ust. 2 i 3 - ograniczone prawo do złożenia wniosku o ponowne rozpatrzenie sprawy. Prawo to ograniczone było tylko do niektórych rozstrzygnięć (stwierdzających niezgodność aktu normatywnego naczelnego lub centralnego organu administracji państwowej lub prezydenta $\mathrm{z}$ konstytucją lub aktem ustawodawczym) co do zakresu podmiotów legitymowanych do wystąpienia z wnioskiem (Rada Ministrów, prezes Rady Ministrów i prezydent ${ }^{11}$ ), jak i terminu (1 miesiąc od doręczenia orzeczenia) ${ }^{12}$. W tym miejscu poczynić należy uwagę, iż instytucja wniosku o ponowne rozpatrzenie sprawy nie stanowiła zwykłego ani nadzwyczajnego

11 W okresie między wejściem w życie ustawy o Trybunale Konstytucyjnym z 1985 r. (tj. dnia 1 stycznia 1986 r.) a jej nowelizacją dokonaną ustawą z dnia 29 maja 1989 r. o przekazaniu dotychczasowych kompetencji Rady Państwa prezydentowi Rzeczypospolitej Polskiej Ludowej i innym organom państwowym (Dz.U. Nr 34, poz. 178), która weszła w życie z dniem 19 lipca 1989 r., organem uprawnionym była Rada Państwa lub przewodniczący Rady Państwa (ówczesny art. 27 ust. 3 starej ustawy o Trybunale Konstytucyjnym).

12 Kwestia ta regulowana była przepisem art. 30 ust. 2 ustawy o Trybunale Konstytucyjnym z 1985 r., który stanowił, iż w wypadku stwierdzenia przez Trybunał Konstytucyjny niezgodności z Konstytucją lub aktem ustawodawczym aktu normatywnego naczelnego lub centralnego organu administracji państwowej Rada Ministrów lub prezes Rady Ministrów może, w ciągu miesiąca od dnia doręczenia orzeczenia, wystąpić z wnioskiem o ponowne rozpatrzenie sprawy przez Trybunał w pełnym składzie. Uprawnienie takie przysługiwało także prezydentowi w wypadku stwierdzenia niezgodności z Konstytucją lub aktem ustawodawczym aktu normatywnego prezydenta lub innego naczelnego lub centralnego organu państwowego niebędącego organem administracji państwowej, z wyłączeniem orze- 
środka odwoławczego, co podkreślił sam Trybunał Konstytucyjny w swoim postanowieniu $^{13}$, argumentując, że instytucja ta polega jedynie na powtórnym zbadaniu zgodności z prawem aktu normatywnego objętego orzeczeniem wydanym w składzie zwykłym ${ }^{14}$. To jedyny skutek, który ustawa wiązała ze złożeniem wniosku o ponowne rozpatrzenie sprawy, bowiem orzeczenia trybunalskie były ostateczne (art. 30 ust. 1 ustawy o Trybunale Konstytucyjnym z 1985 r.), zatem z chwilą ogłoszenia stawały się prawomocne.

Późniejsze nowele do Konstytucji z 1952 r., przyjmowane już po rozpoczęciu w 1989 r. procesu transformacji ustrojowej, rozszerzyły jedynie kompetencje Trybunału o uprzednią kontrolę konstytucyjności ustaw na wniosek prezydenta i ustalanie powszechnie obowiązującej wykładni ustaw ${ }^{15}$ oraz orzekanie o sprzeczności z Konstytucją celów lub działalności partii politycznych ${ }^{16}$. Żadna z nowelizacji nie odnosiła się jednak do ostateczności trybunalskich orzeczeń. Nawet tzw. Mała konstytucja z 1992 r. ${ }^{17}$ utrzymując w mocy przepisy Konstytucji z 1952 r. dotyczące Trybunału Konstytucyjnego, utrwaliła dotychczasowy model kontroli konstytucyjności prawa, w tym także ustaw.

II.

W wyniku zasadniczych zmian ustrojowych po 1989 r., a przede wszystkim przyjęcia zasady demokratycznego państwa prawnego oraz zasady trójpodziału władz, rozpoczęły się prace zmierzające do uchwalenia nowej konsty-

czeń Trybunału dotyczących dekretów (art. 30 ust. 3 ustawy o Trybunale Konstytucyjnym z 1985 r.).

13 Postanowienie Trybunału Konstytucyjnego z dnia 26 października 1988 r., sygn. akt $\mathrm{U} 7 / 88$.

14 Taki pogląd wyraził także Trybunał Konstytucyjny w orzeczeniu z dnia 5 listopada 1986 r., sygn. akt: U 5/86 oraz J. Oniszczuk, Orzecznictwo Trybunatu Konstytucyjnego w latach 1986-1996. Wybrane zagadnienia, Warszawa 1998, s. 47-48.

15 Art. 1 pkt 10 ustawy z dnia 7 kwietnia 1989 r. o zmianie Konstytucji Polskiej Rzeczypospolitej Ludowej (Dz.U. Nr 19, poz. 101).

16 Art. 1 pkt 4 ustawy z dnia 29 grudnia 1989 r. o zmianie Konstytucji Polskiej Rzeczypospolitej Ludowej (Dz.U. Nr 75, poz. 444).

17 Ustawa konstytucyjna z dnia 17 października 1992 r. o wzajemnych stosunkach między władzą ustawodawczą i wykonawczą Rzeczypospolitej Polskiej oraz o samorządzie terytorialnym (Dz.U. Nr 84, poz. 426 ze zm.). 
tucji. Formalny początek prac datowany jest na dzień 7 grudnia 1989 r., kiedy to każda $\mathrm{z}$ izb parlamentu przyjęła uchwały w sprawie powołania Komisji Konstytucyjnej oraz wyboru członków jej składu. Prace każdej z tych Komisji zakończyły się przygotowaniem oddzielnych projektów konstytucji18. Niewątpliwie istnienie dwóch komisji (których prace nie zostały skoordynowane) w latach 1989-1991 utrudniło tylko uchwalenie Konstytucji ${ }^{19}$.

Po pierwszych wolnych wyborach parlamentarnych, które odbyły się w dniu 27 października 1991 r., przed nowo wybranym Sejmem i Senatem stanął problem ustalenia zasad opracowania i przyjęcia nowej konstytucji. Bezspornie należało uregulować wzajemne relacje między dwiema izbami parlamentarnymi, procedurę przygotowywania, składania i przyjmowania projektów nowych regulacji, a w końcu przygotowania końcowego projektu oraz jego uchwalenia. Efektem burzliwych dyskusji w tym przedmiocie była przyjęta Ustawa konstytucyjna o trybie przygotowania i uchwalenia Konstytucji Rzeczypospolitej Polskiej ${ }^{20}$ (dalej jako: ustawa konstytucyjna). Na podstawie art. 4 ust. 1 ustawy konstytucyjnej została utworzona Komisja Konstytucyjna Zgromadzenia Narodowego ${ }^{21}$, która uzyskała prawo inicjatywy ustawodawczej w zakresie przedstawienia Zgromadzeniu Narodowemu projektu nowej konstytucji (art. 2 ust. 1 pkt 1 ustawy konstytucyjnej). Prawo

18 Projekt sejmowej Komisji Konstytucyjnej został odrzucony przez Sejm w dniu 18 października 1991 r. Projekt senackiej Komisji Konstytucyjnej został, na mocy uchwały Senatu z dnia 24 października 1991 r. (Prace Komisji Konstytucyjnej Senatu, Z. 5, s. 182), uznany za materiał legislacyjny, który Senat postanowił przekazać parlamentowi następnej kadencji.

19 Podobnie: R. Chruściak, W. Osiatyński, Tworzenie konstytucji w Polsce $w$ latach 1989-1997, Instytut Spraw Publicznych, Warszawa 2001, s. 62 i n. Przeciwnie: J. Zakrzewska, Spór o konstytucję, „Przegląd Sejmowy” 1993, nr 3, s. 27.

20 Ustawa konstytucyjna z dnia 23 kwietnia 1992 r. o trybie przygotowania i uchwalenia Konstytucji Rzeczypospolitej Polskiej (Dz.U. Nr 67, poz. 336 ze zm.).

${ }^{21}$ W skład Komisji weszło 46 posłów wybranych przez Sejm i 10 senatorów wybranych przez Senat. W posiedzeniach Komisji Konstytucyjnej uczestniczyć mogli, z prawem przedkładania wniosków, upoważnieni przedstawiciele prezydenta, Rady Ministrów oraz Trybunału Konstytucyjnego (art. 4 ust. 3 ustawy z dnia 23 kwietnia 1992 r.). Regulamin Komisji Konstytucyjnej upoważniał do zapraszania na posiedzenia Komisji przedstawicieli partii politycznych niereprezentowanych w Sejmie i Senacie, związków zawodowych i organizacji społeczno-zawodowych o zasięgu ogólnokrajowym, a także przedstawicieli kościołów i związków wyznaniowych w celu przedstawienia opinii (art. 8 ust. 1 regulaminu). 
inicjatywy w zakresie przedstawienia projektu nowej konstytucji, zgodnie $z$ regulacją art. 2 ust. 2 ustawy konstytucyjnej, przyznano także grupie 56 członków Zgromadzenia Narodowego oraz prezydentowi Rzeczypospolitej Polskiej. Projekty nowej konstytucji mogły być składane w terminie sześciu miesięcy od ukonstytuowania się Komisji Konstytucyjnej ${ }^{22}$. Termin złożenia projektów wygasł z dniem 30 kwietnia 1993 r. W tym czasie do Komisji wpłynęło 7 projektów Konstytucji ${ }^{23}$.

Prace Komisji w pierwotnym składzie nie trwały długo, kres położyło im bowiem rozwiązanie Sejmu z dniem 31 maja 1993 r. ${ }^{24}$ Przedterminowe wybory parlamentarne przeprowadzone zostały w dniu 19 września 1993 r. Do ukonstytuowania się Komisji Konstytucyjnej nowej kadencji doszło na pierwszym jej posiedzeniu, które odbyło się dnia 9 listopada 1993 r. Sześciomiesięczny termin wnoszenia do Komisji projektów Konstytucji, zgod-

22 Zgodnie z poglądem R. Chruściaka i W. Osiatyńskiego wybór przewodniczącego i zastępcy oznaczał spełnienie ustawowego wymogu, koniecznego do rozpoczęcia prac Komisji; R. Chruściak, W. Osiatyński, op.cit. s. 105 oraz R. Chruściak, Projekty Konstytucji 1993-1997, część I, Warszawa 1997, s. 7. Wyboru takiego dokonała Komisja na pierwszym posiedzeniu, które odbyło się w dniu 30 października $1992 \mathrm{r}$.

23 Jako pierwszy wpłynął - w dniu 24 marca 1993 r. - projekt podpisany przez 58 posłów i senatorów, którzy stwierdzili, iż składają projekt opracowany przez Komisję Konstytucyjną Senatu I kadencji (dalej jako projekt Senatu I kadencji). Jako drugi został złożony, dnia 28 kwietnia 1993 r., projekt podpisany przez 62 posłów i senatorów członków Klubu Parlamentarnego Sojuszu Lewicy Demokratycznej (dalej jako projekt SLD). Kolejnego dnia - tj. dnia 29 kwietnia 1993 r., złożony został projekt podpisany przez 63 posłów i senatorów członków Klubu Parlamentarnego Unii Demokratycznej (dalej jako projekt UD). W ostatnim dniu terminu składania projektów - dnia 30 kwietnia 1993 r. - wpłynęły łącznie cztery projekty. Pierwszy podpisany przez grupę 61 posłów i senatorów Polskiego Stronnictwa Ludowego i Unii Pracy, przedstawicieli mniejszości niemieckiej, Partii Rencistów i Emerytów „Nadzieja” oraz posłów niezrzeszonych (dalej jako projekt PSL/UD). Drugi podpisany przez ówczesnego prezydenta RP - Lecha Wałęsę (dalej jako: stary projekt prezydenta). Trzeci został podpisany przez 58 członków Zgromadzenia Narodowego, członków Klubu Parlamentarnego Konfederacji Polski Niepodległej oraz pojedynczych posłów (dalej jako projekt KPN). Jako ostatni w dniu 30 kwietnia 1993 r. wpłynął projekt podpisany przez grupę 63 posłów i senatorów, przede wszystkim członków Klubu Parlamentarnego Porozumienia Centrum oraz parlamentarzystów Ruchu dla Rzeczypospolitej i NSZZ „Solidarność” (dalej jako projekt PC).

24 Rozwiązanie nastąpiło na mocy zarządzenia prezydenta Rzeczypospolitej Polskiej z dnia 29 maja 1993 r. w sprawie rozwiązania Sejmu Rzeczypospolitej Polskiej (M.P. Nr 27, poz. 285). 
nie $\mathrm{z}$ regulacją art. 2 ust. 2 ustawy konstytucyjnej, upłynął zatem z dniem 9 maja 1994 r. W tym czasie do Komisji wpłynęły 3 projekty Konstytucji ${ }^{25}$.

W tym miejscu zasygnalizować należy szerzej omawiany zarówno w parlamencie, jak i samej Komisji problem ciągłości prac tejże Komisji ${ }^{26}$. Jak wspominałam - Komisja funkcjonująca w trakcie wcześniejszej kadencji Zgromadzenia Narodowego otrzymała 7 projektów Konstytucji. Po wyborach parlamentarnych pojawił się zatem problem, czy Komisja nowej kadencji zobowiązana była do merytorycznej analizy projektów przedłożonych podczas wcześniejszej kadencji. Ostatecznie problem ten rozstrzygnęła nowelizacja ustawy konstytucyjnej ${ }^{27}$, na mocy której wprowadzono m.in. przepis art. 12a. Przepis ten stanowił, iż projekty konstytucji wniesione na podstawie i w trybie ustawy podlegają rozpatrzeniu przez Komisję Konstytucyjną Zgromadzenia Narodowego bez względu na to, w której kadencji Sejmu i Senatu zostały zgłoszone. W tej sytuacji Komisja Konstytucyjna w składzie ustalonym w październiku 1993 r. do merytorycznego rozpoznania miała 7 projektów złożonych podczas wcześniejszej kadencji Zgromadzenia Narodowego, jak i 3 nowe projekty. Cztery projekty pochodzące z poprzedniej kadencji zostały jednak cofnięte ${ }^{28}$.

Po wspomnianej nowelizacji ustawy konstytucyjnej prawo inicjatywy w zakresie przedstawienia projektu Konstytucji przyznano także grupie obywateli, którzy dla swojego projektu uzyskali poparcie co najmniej 500 000 osób posiadających czynne prawo wyborcze do Sejmu ${ }^{29}$. W tym trybie wpłynął do Komisji Konstytucyjnej projekt podpisany przez 959270 obywateli (dalej jako: projekt obywatelski).

25 Pierwszy w dniu 6 maja 1994 r. podpisany przez prezydenta RP Lecha Wałęsę (dalej jako: projekt prezydenta). Dnia 9 maja 1994 r. zostały złożone dwa projekty - podpisany przez 60 członków Zgromadzenia Narodowego z Klubu Parlamentarnego Unia Demokratyczna (dalej jako projekt UD) oraz kolejny podpisany przez 68 posłów i senatorów członków Klubu Parlamentarnego Sojuszu Lewicy Demokratycznej (dalej jako projekt SLD).

26 Szerzej R. Chruściak, W. Osiatyński, op.cit., s. 228 i n.

27 Ustawa z dnia 22 kwietnia 1994 r. o zmianie ustawy konstytucyjnej o trybie przygotowania i uchwalenia Konstytucji Rzeczypospolitej Polskiej (Dz.U. Nr 61, poz. 251).

28 Oświadczenie o cofnięciu projektu Konstytucji złożył prezydent, przedstawiciele posłów i senatorów SLD i parlamentarzystów Unii Wolności oraz Porozumienie Centrum. R. Chruściak, op.cit., s. 12-13.

29 Art. 2a ust. 1 znowelizowanej ustawy konstytucyjnej. 
Reasumując, Komisja Konstytucyjna Zgromadzenia Narodowego dysponowała siedmioma projektami nowej konstytucji. Były to projekt UD, projekt PSL/UP, projekt KPN, projekt SLD, projekt prezydenta, Projekt Senatu I kadencji i wspomniany już projekt obywatelski. Analizując treść przywołanych projektów konstytucji, dostrzec w nich należy pierwsze próby zmiany modelu kontroli konstytucyjności prawa, jak i pozycji ustrojowej Trybunału Konstytucyjnego. W projektach zasadniczo zarysowały się dwa kierunki w zakresie określenia pozycji ustrojowej Trybunału. Według pierwszego Trybunał został uznany za organ władzy sądowniczej ${ }^{30}$, zgodnie z drugim zaliczony był do instytucji kontrolnych ${ }^{31}$. W jednym przypadku tematyce Trybunału poświęcony był oddzielny rozdział zatytułowany po prostu „Trybunał Konstytucyjny”32. W każdym z projektów różnorako były określane także kompetencje Trybunału. We wszystkich projektach za podstawowe zadanie Trybunału uznawano sprawowanie kontroli zgodności prawa z konstytucją, część projektów wprowadzała formy kontroli konkretnej $\mathrm{w}$ postaci pytania prawnego ${ }^{33}$ czy skargi konstytucyjnej ${ }^{34}$. W myśl niektórych projektów Trybunał zyskiwał dodatkowe kompetencje do np. dokonywania powszechnie obowiązującej wykładni prawa ${ }^{35}$, rozstrzygania sporów kompetencyjnych między władzami publicznymi a sądami ${ }^{36}$, kontroli przeprowadzenia bądź ważności referendum ${ }^{37}$ lub wyborów ${ }^{38}$ oraz różnych form kontroli działania partii politycznych ${ }^{39}$. W projekcie Senatu I kadencji dostrzec także można obligatoryjną kontrolę uprzednią ustaw organicznych ${ }^{40}$,

\footnotetext{
30 Projekt UD, projekt prezydenta.

31 Projekt Senatu I kadencji, projekt obywatelski.

32 Projekt PSL/UP.

33 Projekt prezydenta, projekt PSL/UP.

34 Projekt prezydenta, projekt UD.

35 Projekt PSL/UP, projekt UD, projekt obywatelski.

36 Projekt prezydenta.

37 Projekt prezydenta, projekt SLD, projekt Senatu I kadencji.

38 Projekt SLD.

39 Projekt SLD, projekt Senatu I kadencji, projekt PSL/UP, projekt UD.

40 „Ustawa organiczna” to przewidziany w projekcie Senatu I kadencji nowy rodzaj ustawy o szczególnej doniosłości. Różnić miała się ona od ustawy zwykłej kwalifikowanym trybem uchwalenia i zmiany oraz przedmiotem regulacji i formą obligatoryjnej kontroli jej legalności przez Trybunał Konstytucyjny jeszcze przed ogłoszeniem. Zastrzeżona była dla normowania najważniejszych materii ustrojowych.
} 
które przed ich ogłoszeniem powinny być przedstawione Trybunałowi Konstytucyjnemu, który miał wypowiedzieć się co do ich zgodności z Konstytucją (art. 153 ust. 2), a w razie stwierdzenia sprzeczności z Konstytucją akt nie mógł być ogłoszony ani wejść w życie (art. 154). Przykładowo, w propozycji Konfederacji Polski Niepodległej, Trybunał Konstytucyjny wyposażony był w dodatkowe kompetencje charakterystyczne dla Trybunału Stanu. Wszystkie projekty zawierały także postanowienie, że organizację i tryb postępowania przed Trybunałem określi ustawa ${ }^{41}$.

Zasadniczą zmianę w odniesieniu do obowiązujących wówczas uregulowań prawnych dostrzec jednak należy w zakresie skutków prawnych orzeczeń trybunalskich. Część z projektów zawierała wprost postanowienie, iż orzeczenia Trybunału Konstytucyjnego mają moc powszechnie obowiązującą i są ostateczne ${ }^{42}$. Moc powszechnie obowiązująca i ostateczność tych orzeczeń dodatkowo podkreślona była w projekcie prezydenta poprzez wskazanie, iż orzeczenia sądów i trybunałów nie mogą być zmieniane ani uchylane przez organy władzy ustawodawczej lub wykonawczej (art. 101 ust. 1). W projekcie obywatelskim przewidziano, że akt prawny uznany przez Trybunał za sprzeczny z Konstytucją nie może być ogłoszony ani nie może wejść w życie (art. 146 ust. 2). Postanowienia najbardziej zbliżone do regulacji z Konstytucji z 1952 r. przewidywał projekt Sojuszu Lewicy Demokratycznej. W tym projekcie skutki orzeczeń Trybunału o niezgodności rozróżniono w zależności od rangi aktu prawnego, którego dotyczyło orzeczenie. Zgodnie bowiem z treścią projektu orzeczenie o niezgodności ustawy z Konstytucją Trybunał miał kierować do Sejmu, który w czasie nie dłuższym niż 6 miesięcy powinien doprowadzić do zgodności ustawy z Konstytucją, po bezskutecznym upływie tego terminu akt miał tracić moc, co miał obwieszczać prezes Trybunału (art. 155 ust. 2). Niewątpliwie Sejm miał być pozbawiony możliwości odrzucenia orzeczenia Trybunału, niemniej orzeczenie to nie było skuteczne z momentem jego wydania. Orzeczenia Trybunału o niezgodności innych niż ustawa aktów prawodawczych władz publicznych

${ }^{41}$ Na przykład projekt prezydenta, projekt SLD - choć tu ustawa organiczna, projekt PSL, projekt KPN, projekt UD, projekt obywatelski.

42 Przepis taki znajdował się w art. 151 projektu Senatu I kadencji, art. 118 projektu PSL, art. 154 projektu UD, które to projekty podlegały rozpatrzeniu na podstawie art. 12a ustawy konstytucyjnej z dnia 23 kwietnia 1992 r. 
miały być wiążące z chwilą ich ogłoszenia (art. 155 ust. 3). Projekt SLD uznawał, że orzeczenia Trybunału wydane w wyniku rozpatrzenia skargi kasacyjnej obywatela będą ostateczne (art. 156).

Podsumowując tę część rozważań, podkreślić należy, że większość projektów nowej konstytucji przygotowanych przez partie polityczne zawierała postanowienia o tym, iż orzeczenia Trybunału powinny mieć moc powszechnie obowiązującą i być ostateczne. Taka zgoła odmienna od regulacji obowiązującej po 1982 r. formuła niewątpliwie była przejawem przemian ustrojowych zmierzających do odcięcia się od systemu państwa socjalistycznego. Świadczy również o dojrzałym dialogu politycznym zmierzającym do budowy modelu kontroli konstytucyjności prawa odpowiadającego standardom demokratycznego państwa prawnego.

Zakończenie etapu wnoszenia projektów konstytucji pozwoliło Komisji Konstytucyjnej na przejście do kolejnego etapu prac, czyli czytania projektów, które odbyło się podczas Zgromadzenia Narodowego obradującego między 21 a 23 września 1994 r. Po zakończeniu dyskusji żaden z projektów nie został odrzucony, zatem wszystkie zostały skierowane do Komisji Konstytucyjnej, która przystąpiła do opracowania projektu Konstytucji, który miał być przedstawiony do uchwalenia Zgromadzeniu Narodowemu.

Początkowo prace nad poszczególnymi rozdziałami projektu odbywały się $\mathrm{w}$ podkomisjach stałych. Efektem tych prac było zredagowanie ostatecznie w dniu 20 stycznia 1995 r. projektu jednolitego konstytucji w ujęciu wariantowym. W odniesieniu do mocy prawnej i skutków orzeczeń Trybunału w rzeczonym projekcie zawarto cztery warianty proponowanego uregulowania $^{43}$. Najdalej idące uregulowanie zawarte było w wariancie pierwszym art. 171, w którym wskazano, że orzeczenia Trybunału mają moc powszechnie obowiązującą i są ostateczne. Kolejne warianty statuowały wyjątki, przewidując, iż Sejm mógł zawiesić wykonalność orzeczenia (wariant II) lub odrzucić orzeczenie (wariant III i IV), które wiązałoby się z nakładami finansowymi nieprzewidzianymi w ustawie budżetowej (wariant II i IV) lub naruszały równowagę budżetową (wariant III). W każdym z tych przypadków zawieszenie lub odrzucenie orzeczenia przez Sejm następować miało kwalifiko-

43 R. Chruściak, Projekty Konstytucji 1993-1997, część II, Warszawa 1997, s. 65. 
waną większością głosów (co najmniej 2/3 głosów w obecności przynajmniej połowy ogólnej liczby posłów).

Projekt konstytucji z dnia 20 stycznia 1995 r. stał się przedmiotem obrad Komisji Konstytucyjnej w dniach 25-27 stycznia 1995 r. Obrady te zakończyły się opracowaniem kolejnego projektu jednolitego konstytucji w ujęciu wariantowym. Regulacja art. 171 dotycząca mocy obowiązującej orzeczeń Trybunału nie była zmieniona przez Komisję Konstytucyjną i została skierowana do prac tejże Komisji w czterech - opisanych powyżej wariantach.

Po tej dacie rozpoczął się kolejny etap prac Komisji Konstytucyjnej, podczas którego Komisja systematycznie rozpatrywała kolejne przepisy projektu. Najważniejsze z punktu widzenia tematu niniejszej pracy było 23. posiedzenie Komisji, które obyło się w dniach 5 i 6 września 1995 r. oraz 46. posiedzenie Komisji odbyte dnia 27 września 1995 r. $^{44}$

W drugim dniu obrad 23. posiedzenia Komisji poseł Włodzimierz Cimoszewicz, przy okazji dyskusji nad przyznaniem orzeczeniom Trybunału Konstytucyjnego przymiotu ostateczności, zaproponował projekt przyjęcia regulacji stanowiącej o upoważnieniu Trybunału do określenia innego terminu utraty mocy obowiązującej aktu normatywnego, którego sprzeczność z Konstytucją stwierdzono, niż pokrywający się z dniem ogłoszenia orzeczenia Trybunału Konstytucyjnego ${ }^{45}$. Poseł W. Cimoszewicz zwrócił uwagę, iż $\mathrm{w}$ dotychczasowym stanie prawnym orzeczenia Trybunału Konstytucyjnego podlegały rozpatrzeniu przez Sejm i mogły być odrzucone. Tymczasem, jak dalej argumentował, w rozwoju państwa, w tym także konstytucjonalizmu, doszliśmy do takiego momentu, kiedy trzeba zaprzestać dotychczasowej praktyki i nadać orzeczeniom Trybunału Konstytucyjnego nie tylko moc powszechnie obowiązującą, ale i ostateczny charakter. Zdaniem posła zaproponowane rozwiązanie - dotyczące określenia innego terminu utraty mocy obowiązującej rozstrzygnięć trybunalskich - to mechanizm, który może zapobiec dramatycznym sytuacjom w praktyce, kiedy orzeczenie jest niewykonalne. Apelując do uczestników obrad, poseł skonkludował swoją

44 R. Chruściak, W. Osiatyński, op.cit., s. 103-110.

45 Biuletyn Komisji Sejmowych Nr 1848/II, http://orka.sejm.gov.pl/Biuletyn.nsf (1.12.2014) oraz Biuletyn Komisji Konstytucyjnej Zgromadzenia Narodowego nr XXIV, Warszawa 1996, s. 83 i n. (dalej jako Biuletyn KK ZN). 
wypowiedź wnioskiem o rozszerzenie formuły przepisu art. 171 ust. $3^{46}$ projektu jednolitego konstytucji o zdanie w następującym brzmieniu: „W przypadku orzeczeń, które wiążą się z nakładami finansowymi nieprzewidzianymi w ustawie budżetowej, Trybunał Konstytucyjny określa termin utraty mocy obowiązującej aktu normatywnego po zapoznaniu się z opinią Rady Ministrów”. Jeszcze raz uzasadniając swój wniosek, poseł wskazał, iż chodzi o to, aby Trybunał miał niekwestionowane prawo do samodzielnego określenia takiego terminu, ale żeby mógł zapoznać się z argumentacją władzy wykonawczej, która byłaby np. odpowiedzialna za zrealizowanie wydatków nieprzewidzianych w ustawie budżetowej. W zależności od swej woli Trybunał mógłby wziąć pod uwagę tego typu opinię lub ją odrzucić.

$\mathrm{Na}$ dalszym etapie dyskusji przedstawiciel Trybunału Konstytucyjnego prof. Andrzej Zoll niewątpliwie pozytywnie ocenił koncepcję W. Cimoszewicza, zwracając uwagę na regulację obowiązującą w trybunale austriackim, który to ma możliwość odroczenia wejścia w życie orzeczenia w tym sensie, że wyznaczony zostaje parlamentowi określony termin do wprowadzenia poprawki. Nie może być to dowolność ze strony Trybunału, bo mogłoby tu wystąpić pole pewnej manipulacji ${ }^{47}$. Niewątpliwym ratio legis proponowanej regulacji - w opinii A. Zolla - miało być danie szansy parlamentowi na poprawienie swojego błędu. Późniejsza praktyka pozwoli kontestować wykorzystanie przez ustawodawcę czasu odroczenia na skorygowanie swoich błędów.

Przedmiotem dalszej dyskusji w drugim dniu 23. posiedzenia Komisji było zagadnienie dotyczące umiejscowienia proponowanej regulacji w tym znaczeniu, czy powinna znaleźć się ona w Konstytucji, czy ustawie regulującej postępowanie przed Trybunałem Konstytucyjnym. Zasadnicza część dyskusji skupiła się także nad oceną, czy wprowadzić możliwość odroczenia utraty mocy obowiązującej w odniesieniu do każdej z materii, czy ograniczyć jej zakres np. do spraw związanych z nakładami finansowymi. Rozprawiano również, czy wymagane jest współdziałanie organów państwa w kwestii oceny, czy w danej sprawie celowe jest zastosowanie odroczenia.

46 Przepis art. 190 ust. 3 Konstytucji w jednolitym projekcie Konstytucji będącym przedmiotem dyskusji podczas 23. posiedzenia Komisji Konstytucyjnej Zgromadzenia Narodowego w dniach 5 i 6 września 1995 r. stanowił art. 171 ust. 3.

47 Biuletyn Komisji Sejmowych Nr 1848/II, http://orka.sejm.gov.pl/Biuletyn.nsf (1.12.2014) oraz Biuletyn KK ZN nr XXIV, Warszawa 1996, s. 85 i n. 
Bezspornie pozytywnie ocenić należy wnioski członków Komisji wskazujące na to, iż precyzyjnie należy określić termin, na który Trybunał Konstytucyjny może odroczyć utratę mocy obowiązującej aktu normatywnego.

Na końcowym etapie obrad w dniu 6 września 1995 r. proponowana regulacja została przedstawiona $\mathrm{w}$ brzmieniu odpowiadającym niemalże obecnej regulacji art. 190 ust. 3 Konstytucji RP. Włodzimierz Cimoszewicz podsumowując dyskusję, stwierdził, iż: „uprawnienie Trybunału Konstytucyjnego do wyznaczania terminu utraty mocy obowiązującej przez zakwestionowany akt normatywny dotyczyłoby wszystkich przypadków, natomiast w przypadku aktów normatywnych wywołujących konsekwencje nieprzewidziane w ustawie budżetowej taka decyzja byłaby poprzedzona opinią Rady Ministrów"48.

Rekapitulując, członkowie Komisji, w tym także przedstawiciele Trybunału Konstytucyjnego, niewątpliwie pozytywnie ocenili regulację zgłoszoną przez W. Cimoszewicza. Podobną ocenę przedstawiają także Ryszard Chruściak i Wiktor Osiatyński ${ }^{49}$.

Przedstawiona przez posła W. Cimoszewicza propozycja regulacji treści obecnego art. 190 ust. 3 Konstytucji, określona jako wspólny projekt przedstawiciela Trybunału Konstytucyjnego - prof. Janusza Trzcińskiego i posła $^{50}$, poddana została pod głosowanie w dniu 26 września 1995 r. podczas 46. posiedzenia Komisji Konstytucyjnej Zgromadzenia Narodowego ${ }^{51}$. Podsumowując wyniki tego głosowania, prowadzący posiedzenie poseł Aleksander Kwaśniewski stwierdził, iż „podjęliśmy jedną z najważniejszych decyzji w trakcie dotychczasowych prac nad projektem konstytucji. Będzie to być może nawet decyzja historyczna, jeżeli uzyska poparcie w dalszych pracach konstytucyjnych" 52 .

48 Biuletyn Komisji Sejmowych Nr 1848/II, http://orka.sejm.gov.pl/Biuletyn.nsf (1.12.2014) oraz Biuletyn KK ZN nr XXIV, Warszawa 1996, s. 98.

49 R. Chruściak, W. Osiatyński, op.cit., s. 274.

50 Komisja Konstytucyjna Zgromadzenia Narodowego (1 czerwca-15 września 1995 r.), „Przegląd Sejmowy” 1995, nr 3, s. 221.

51 Biuletyn Komisji Sejmowych Nr 1919/II, http://orka.sejm.gov.pl/Biuletyn.nsf (1.12.2014) oraz Biuletyn KK ZN nr XXV, Warszawa 1996, s. 85 i n.; Komisja Konstytucyjna Zgromadzenia Narodowego (16 września-23 grudnia 1995 r.), „Przegląd Sejmowy” 1995, nr 4, s. $287 \mathrm{in}$.

52 Biuletyn Komisji Sejmowych Nr 1919/II, http://orka.sejm.gov.pl/Biuletyn.nsf (1.12.2014) oraz Biuletyn KK ZN nr XXV, Warszawa 1996, s. 87. 
W konkluzji wspomnieć pragnę, iż Komisja Konstytucyjna Zgromadzenia Narodowego zakończyła prace na posiedzeniu w dniu 16 stycznia 1997 r. W toku tych prac nie powracano już do kwestii odroczenia wejścia w życie orzeczenia Trybunału Konstytucyjnego. Przedstawiony przez Komisję projekt konstytucji trafił pod obrady Zgromadzenia Narodowego dnia 24 lutego 1997 r., a Konstytucja Rzeczypospolitej Polskiej uchwalona została podczas drugiego czytania, które odbyło się dnia 2 kwietnia 1997 r. Referendum konstytucyjne odbyło się w dniu 25 maja 1997 r. Ówczesny prezydent RP Aleksander Kwaśniewski podpisał nową Konstytucję w dniu 16 lipca 1997 r. podczas uroczystości w Pałacu Prezydenckim. Z tą samą datą ukazał się Dziennik Ustaw Nr 78, w którym pod pozycją 483 został opublikowany tekst ustawy zasadniczej. Konstytucja, stosownie do regulacji zawartego w niej art. $243^{53}$, weszła w życie z dniem 17 października 1997 r.

Podsumowując - niewątpliwie idea wprowadzenia do polskiego systemu prawa regulacji ustanawiającej kompetencję dla Trybunału Konstytucyjnego do odroczenia utraty mocy obowiązującej zakwestionowanego aktu normatywnego pochodziła od ówczesnych członków Trybunału ${ }^{54}$. Skazana na niepowodzenie będzie zatem próba kontestowania tego, iż idea omawianej instytucji wynikała $\mathrm{z}$ doświadczeń sędziów Trybunału Konstytucyjnego, a jako taka miała duży walor praktyczny. Prace Komisji Konstytucyjnej były na bieżąco komentowane przez przedstawicieli Trybunału Konstytucyjnego. Profesor Zdzisław Czeszejko-Sochacki, oceniając projekty konstytucji w zakresie ostateczności orzeczeń Trybunału, dopuszczał możliwość szczególnych rozwiązań w razie kryzysu (załamania) gospodarczego, podkreślając, że stan ten musi być „wyraźnie (w sposób poddający się kontroli) określony, czasowo ograniczony, aby nie stać się chronicznym zjawiskiem, a wreszcie nadzwyczajne środki stosowane w tym czasie musiałyby być sprecyzowane i poddane kontroli" ${ }^{55}$. Pozytywną ocenę instytucji odroczenia do-

53 Przepis ten stanowi, iż Konstytucja Rzeczypospolitej Polskiej wchodzi w życie po upływie 3 miesięcy od dnia jej ogłoszenia.

54 Informacje: Komisja Konstytucyjna Zgromadzenia Narodowego (1 czerwca-15 września 1995 r.), „Przegląd Sejmowy” 1995, nr 3, s. 221. Podobny pogląd prezentuje J. Ciemniewski, Trybunat Konstytucyjny jako przedmiot prac nad konstytucją III Rzeczypospolitej, [w:] Trybunat Konstytucyjny Księga XV-lecia, Warszawa 2001, s. 24.

55 Z. Czeszejko-Sochacki, Trybunat Konstytucyjny w świetle projektów Konstytucji RP, „Państwo i Prawo” 1995, z. 2, s. 19 oraz idem, Skutki prawne orzeczenia przez Trybunat Kon- 
strzec można również w wypowiedzi prof. Leszka Garlickiego, który jednakże zwracał uwagę na trudności w precyzyjnym zdefiniowaniu rozwiązania ${ }^{56}$. Leszek Garlicki podkreślił, iż rolą nowej ustawy o Trybunale Konstytucyjnym będzie rozstrzygnięcie tak istotnych kwestii jak ocena, czy zakwestionowana regulacja normatywna, jeszcze przed pozbawieniem mocy obowiązującej, będzie znajdowała zastosowanie do spraw indywidualnych, oraz to, czy sposób ustalania opóźnienia w utracie mocy obowiązującej dotyczy tylko niektórych przepisów uznanych za niekonstytucyjne. Wskazywał także na celowość stworzenia wyjątku dla sytuacji prawnej skarżącego w sprawach ze skarg konstytucyjnych i pytań prawnych, w przeciwnym wypadku poddając w wątpliwość sens każdej z tych instytucji ${ }^{57}$.

Konstytucja z 1997 r. w art. 190 ust. 1 przyjęła expressis verbis zasadę, iż orzeczenia Trybunału Konstytucyjnego mają moc powszechnie obowiązującą i są ostateczne. Zasada ta została wypowiedziana przez ustrojodawcę konstytucyjnego w sposób kategoryczny i bezwzględny, bez żadnych ograniczeń czy warunków. Jedyny wyłom w tej zasadzie miał charakter czasowy i regulowany był w treści art. 239 ust. 1 Konstytucji. Przepis ten określał, iż w okresie 2 lat od dnia wejścia w życie Konstytucji orzeczenia Trybunału Konstytucyjnego o niezgodności z Konstytucją ustaw uchwalonych przed dniem jej wejścia w życie nie są ostateczne i podlegają rozpatrzeniu przez Sejm, który może odrzucić takie orzeczenie większością $2 / 3$ głosów, w obecności co najmniej połowy ustawowej liczby posłów. Nie dotyczyło to orzeczeń wydanych w następstwie pytań prawnych. Analizując przytoczoną regulację przejściową, dostrzec należy jej ograniczenie w czasie (2 lata od dnia wejścia w życie Konstytucji) oraz to, że znajduje ona swoje zastosowanie wyłącznie do ustaw, i to tylko uchwalonych przed dniem wejścia w życie Konstytucji. Sejm miał prawo rozpatrzyć orzeczenie maksymalnie w terminie sześciu miesięcy od dnia przedłożenia go przez prezesa Trybunału (art. 89 ust. 2 ustawy o Trybunale Konstytucyjnym). W razie uchybienia temu terminowi orzeczenie Trybunału stawało się ostateczne i skutkowało wyeliminowaniem z obrotu prawnego zakwestio-

stytucyjny o niekonstytucyjności aktu normatywnego, „Przegląd Sejmowy” 1996, nr 3, s. 19 i n.

56 L. Garlicki, Trybunat Konstytucyjny w projekcie Komisji Konstytucyjnej Zgromadzenia Narodowego, „Państwo i Prawo” 1996, z. 2, s. 10.

57 Autor publikacji zastanawiał się nad zjawiskiem, które w chwili obecnej nazywamy „przywilejem korzyści”. 
nowanych przez Trybunał przepisów z dniem ogłoszenia w Dzienniku Ustaw RP obwieszczenia prezesa Trybunału o utracie mocy obowiązującej (art. 89 ust. 4 ustawy o Trybunale Konstytucyjnym). W okresie obowiązywania komentowanego wyjątku Trybunał wydał 18 wyroków, z czego Sejm odrzucił $3^{58}$. Prezes Trybunału opublikował w Dzienniku Ustaw pięć obwieszczeń w trybie art. 89 ust. 4 ustawy o Trybunale Konstytucyjnym ${ }^{59}$.

\section{III.}

Założony na wstępie opracowania cel - omówienie procesu kształtowania się ostateczności orzeczeń Trybunału Konstytucyjnego w okresie od 1982 do 1997 r. - pozwala na postawienie tezy, iż ten właśnie czas był najważniejszym okresem w historii polskiego sądownictwa konstytucyjnego w zakresie kształtowania się ostateczności orzeczeń Trybunału Konstytucyjnego, a przez to także pozycji samego Trybunału w systemie organów państwa. Niewątpliwie uwarunkowania systemu politycznego obowiązującego przed 1989 r. pozwalały jedynie na posługiwanie się metodą małych kroczków. Ewolucja była powolna, ale sukcesywna i - co pokazano w pracy - skuteczna. Ostateczność została przypisana początkowo tylko do orzeczeń odnoszących się do aktów prawnych rangi niższej niż ustawa. Takie pierwsze nieśmiałe rozwiązania umacniały jednak pozycję Trybunału Konstytucyjnego, który stawał się organem niezależnym od władzy ustawodawczej, co w systemach państw demokratycznych jest podstawowym założeniem. Niewątpliwie w trakcie prac nad tekstem nowej ustawy zasadniczej ostateczność orzeczeń Trybunału była jednym z najbardziej spornych zagadnień. Uchwalenie w 1992 r. tzw. Małej konstytucji nie wprowadziło rewolucyjnych zmian. Ustrojodawca definitywnie przewidział pełny model ostateczności orzeczeń $^{60}$ dopiero w Konstytucji z 1997 r., jednakże ten model w sposób de-

58 M. Florczak-Wątor, op.cit., s. 53 i n.

59 Obwieszczenia dotyczyły wyroków TK: z dnia 8 kwietnia 1997 r., sygn. akt K 14/96; z dnia 28 maja 1997 r., sygn. akt K 26/96; z dnia 6 października 1998 r., sygn. akt K 36/97; z dnia 27 stycznia 1999 r., sygn. akt K 1/98; z dnia 25 lutego 1999 r., sygn. akt K 23/98.

60 Chodzi tu o model ostateczności rozumianej jako ostateczność orzeczeń, która nie była uzależniona od zgody czy woli jakiegokolwiek innego organu niż sam Trybunał. 
finitywny zaczął funkcjonować dopiero po 1999 r. W ustawie zasadniczej z 1997 r. orzeczeniom Trybunału Konstytucyjnego nadano bowiem moc powszechnie obowiązującą i ostateczność (art. 190 Konstytucji), jednak z wyjątkiem zawartym w art. 239 Konstytucji, który to - na szczęście - miał charakter czasowy (obowiązywał do 1999 r.).

\section{Literatura}

Chruściak R., Osiatyński W., Tworzenie konstytucji w Polsce w latach 1989-1997, Instytut Spraw Publicznych, Warszawa 2001.

Chruściak R., Projekty Konstytucji 1993-1997, część I, Warszawa 1997.

Chruściak R., Projekty Konstytucji 1993-1997, część II, Warszawa 1997.

Ciemniewski J., Trybunał Konstytucyjny jako przedmiot prac nad konstytucja III Rzeczypospolitej, [w:] Trybunat Konstytucyjny Księga XV-lecia, Warszawa 2001.

Czeszejko-Sochacki Z., Skutki prawne orzeczenia przez Trybunat Konstytucyjny o niekonstytucyjności aktu normatywnego, „Przegląd Sejmowy” 1996, nr 3.

Czeszejko-Sochacki Z., Trybunał Konstytucyjny w świetle projektów Konstytucji RP, „Państwo i Prawo” 1995, z. 2.

Garlicki L., Trybunat Konstytucyjny w projekcie Komisji Konstytucyjnej Zgromadzenia Narodowego, „Państwo i Prawo” 1996, z. 2.

Komisja Konstytucyjna Zgromadzenia Narodowego (1 czerwca-15 września 1995 roku), „Przegląd Sejmowy” 1995, nr 3.

Mazurkiewicz M., Orzecznictwo Trybunatu Konstytucyjnego jako inspiracja w pracach nad Konstytucja z dnia 2 kwietnia 1997 roku, [w:] Księga XX-lecia orzecznictwa Trybunału Konstytucyjnego, Warszawa 2006.

Oniszczuk J., Orzecznictwo Trybunatu Konstytucyjnego w latach 1986-1996. Wybrane zagadnienia, Warszawa 1998.

Skrzypczak T., Wykładnia autentyczna czy nowy rodzaj normy prawnej, [w:] Konstytucja w społeczeństwie obywatelskim. Ksiegga pamiątkowa ku czci Prof. W. Zakrzewskiego, red. K. Działocha, Kraków 1989.

Zakrzewska J., Spór o konstytucję, „Przegląd Sejmowy” 1993, nr 3. 